\title{
EVIDENCE THAT REMOVAL OF AN ENDOGENOUS METAL THAT STABILIZES THE UNTRANSFORMED GLUCOCORTICOID RECEPTOR IN CYTOSOL ALLOWS LIGAND-INDEPENDENT RECEPTOR TRANSFORMATION
}

\begin{abstract}
Soheil Meshinchi and William B. Pratt
Department of Pharmacology, The University of Michigan Medical School, Ann Arbor, MI 48109, U.S.A.

Summary - Cytosol preparations contain an endogenous heat-stable factor which stabilizes the glucocorticoid receptor in its untransformed, non DNA-binding form. Elution of a partially purified preparation of this stabilizing factor through a metal chelating resin (Chelex-100) leads to the loss of its ability to inhibit temperature-mediated transformation of the receptor. Sodium molybdate mimicks the ability of this endogenous metal to stabilize the untransformed receptor, and it too is adsorbed by Chelex resin. When an L-cell cytosol preparation containing the glucocorticoid receptor is passed through a column of Chelex-100 resin and then incubated at $15^{\circ} \mathrm{C}$, the receptor is rapidly transformed to the DNA-binding state, regardless of whether it is steroid-bound or not. In contrast, whole cytosol containing endogenous metals is transformed to the DNA-binding state only when the receptor is both steroid-bound and exposed to elevated temperature. these data suggest that a metal (or metals) may be involved in conferring the property of ligand-dependency to the transformation process.
\end{abstract}

\section{INTRODUCTION}

Transformation of cytosolic glucocorticoid receptor form a non DNA-binding state to a state that binds DNA is both a temperature-dependent and a liganddependent process [1-3]. The mechanism by which the steroid promotes temperature mediated transformation is poorly understood, although there is considerable evidence that binding of steroid in some way facilitates dissociation of the receptor from the $90 \mathrm{kDa}$ heat shock protein, hsp90 [1, 2]. Sanchez et al.[2] have shown that dissociation of hsp 90 from the receptor complex in L-cell cytosol is also a steroiddependent and a temperature-dependent event. Recently, we demonstrated that cytosols contain an endogenous metal which stabilizes the glucocorticoid receptor in its untransformed, non-DNA-binding form [4]. The activity of this endogenous stabilizing factor is mimicked by group VI-A transition metal oxyanions such as molybdate or vanadate. The ability of this endogenous metal anion to stabilize the receptor in its non-DNA-binding form in association with hsp90 has led to the hypothesis that the metal acts as an endogenous stabilizing component of the untransformed receptor complex. This study examines the transformation of glucocorticoid receptors in L-cell cytosol from which the endogenous metal has been removed by chelation.

Proceedings of the 9th International Symposium of the Journal of Steroid Biochemistry, Recent Advances in Steroid Biochemistry, Las Palmas, Canary Islands, Spain, 28-31 May 1989.

\section{EXPERIMENTAL}

\section{Chemicals}

$\left[6,7{ }^{3} \mathrm{H}\right]$ Triamcinolone acetonide $(42.8 \mathrm{Ci} / \mathrm{mmol})$, and ${ }^{125} \mathrm{I}$-conjugated goat anti-mouse IgG was obtained from New England Nuclear, Boston, Mass. Radioinert dexamethasone, rabbit anti-goat IgG-horseradish peroxidase conjugate, sodium molybdate, hepes buffer and marker proteins were from Sigma Chemical Co., St Louis, Mo. Chelex-100 chelating ion exchange resin and chemicals for electrophoresis were from Bio-Rad Laboratories, Richmond, Calif. Immobilon-P transfer membrane $(0.45 \mu \mathrm{m})$ was from Millipore, Bedford, Mass. The BuGR2 antiglucocorticoid receptor monoclonal antibody was kindly provided by $\mathrm{Dr}$ R. W. Harrison[5].

\section{Cell source and fractionation}

L-cells were grown in monolayer culture in Dulbecco's modified cagle medium supplemented with $10 \%$ calf serum at $37^{\circ} \mathrm{C}$. Cells were harvested by scraping and washed in Earle's balanced saline. The cell pellet was suspended in 1.5 volumes of $10 \mathrm{mM}$ hepes, $0.1 \mathrm{mM}$ EDTA, pH 7.4 at $4^{\circ} \mathrm{C}$, and ruptured by Dounce homogenization. The homogenate was centrifuged at $100,000 \mathrm{~g}$. The supernatant (referred to as cytosol) was used immediately.

\section{Preparation of stabilizing factor}

Stabilizing factor was prepared from boiled rat liver cytosol as described previously [4], and was concentrated 16-fold. The concentration of factor is 
expressed in relative units, with one relative unit of factor being the concentration of factor normally present in L-cell cytosol.

\section{Chelex treatment of factor and molybdate}

Chelex-100 resin was washed and equilibrated with $10 \mathrm{mM}$ Hepes buffer, $\mathrm{pH} 7.4$. An aliquot $(0.5 \mathrm{ml})$ of 16-fold concentrated factor or $0.2 \mathrm{ml}$ of $25 \mathrm{mM}$ sodium molybdate was placed on a $1.5 \times 10 \mathrm{~cm}$ column of Chelex resin. Columns were eluted with $10 \mathrm{mM}$ Hepes buffer $\mathrm{pH}$ 7.4. Drop-through fractions were pooled and concentrated to original volume by lyophilization.

\section{Chelex treatment of cytosol}

Chelex resin was washed extensively and equilibrated with $10 \mathrm{mM}$ hepes buffer, $\mathrm{pH} 7.4$, was placed in a $10 \mathrm{ml}$ syringe and centrifuged inside a $30 \mathrm{ml}$ Corex tube at $10,000 \mathrm{~g}$ in order to remove buffer from within the beads. Steroid-free L-cell cytosol was placed on top of the resin in a 1:4 ratio (cytosol vol:resin vol), and centrifuged immediately. This method allows for Chelex-treatment of cytosol without dilution of the receptor and with minimum loss of steroid-binding activity.

\section{Assay for inhibition of transformation}

Transformation inhibiting activity was assayed by adding various concentrations of indicated samples to $225 \mu$ l of cytosol prebound with $\left[{ }^{3} \mathrm{H}\right]$ triamcinolone acetonide. The total incubation volume was adjusted to a volume of $450 \mu 1$ and a final DTT concentration of $10 \mathrm{mM}$. Each sample was incubated for $60 \mathrm{~min}$ at $20^{\circ} \mathrm{C}$ and the amount of receptor transformation was measured by binding to DNA-cellulose as described previously [4].

\section{Quantitative western immunoblotting of DNA-bound receptor}

For the experiment in Fig. 2, DNA-bound receptor was extracted from DNA-cellulose with SDS sample buffer containing $10 \% \beta$-mercaptoethanol. Proteins were resolved by SDS-polyacrylamide gel electrophoresis on $7 \%$ slab gels. Proteins were transferred from the slab gel to Immobilon-P transfer membrane and probed with BuGR2 monoclonal anti-receptor antibody. The membrane was subsequently probed with a ${ }^{125}$ I-conjugated goat anti-mouse antibody and was then visualized by probing with a horseradish peroxidase-conjugated rabbit anti-goat antibody. After autoradiography of the western blot, the receptor bands were excised and quantitated by scintillation counting. The results are presented as the percent of total receptor bound to DNA-cellulose.

\section{RESULTS AND DISCUSSION}

In our original work [6], we showed that a low molecular weight, heat-stable component of rat liver cytosol stabilizes the unliganded glucocorticoid re-

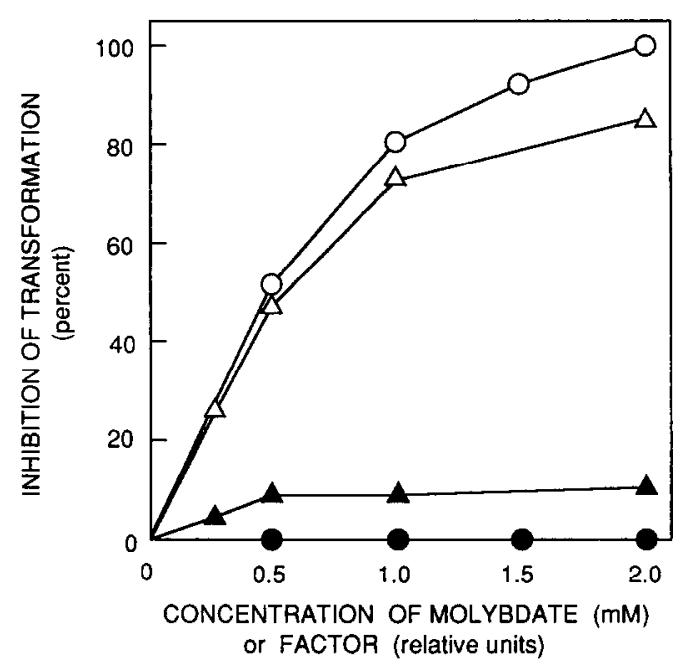

Fig. 1. Chelex-treatment eliminates the ability of both the stabilizing factor and sodium molybdate to inhibit receptor transformation at $20^{\circ} \mathrm{C}$. An aliquot of the factor preparation or a sodium molybdate solution was eluted through a column of Chelex resin as described under "Experimental". Aliquots of whole L-cell cytosol containing steroid-bound receptors were incubated for $60 \mathrm{~min}$ at $20^{\circ} \mathrm{C}$ with various concentrations of the factor preparation $(\triangle)$, molybdate $(\mathrm{O})$, Chelex-treated factor $(\boldsymbol{\Lambda})$, or Chelextreated molybdate (O). At the end of the incubation, binding to DNA-cellulose was assayed as described under "Experimental". The data are presented as the percent inhibition of transformation.

ceptor against temperature-mediated inactivation of steroid binding capacity. The same heat-stable component also inhibited temperature-mediated transformation of the steroid-bound receptor to the DNA-binding form [6]. This low molecular weight factor, which produces the same biological effects on the receptor as sodium molybdate, was shown to be a metal anion with the same size, charge and chelation properties as molybdate [4]. As shown in Fig. 1, addition of either the stabilizing factor or sodium molybdate to whole (i.e. not Chelex-treated) L-cell cytosol inhibits temperature-mediated conversion of steroid-bound receptor to the DNAbinding form in a concentration-dependent manner. However, when either the factor preparation or a sodium molybdate solution is eluted through a column of the metal chelating resin, Chelex-100, the Chelex-treated material is devoid of stabilizing activity. This suggests that a metal component of the factor preparation is required for its receptor stabilizing effect.

To investigate the possible functional significance of the endogenous metal in receptor transformation, we depleted cytosol of its metal components by passing the cytosol preparation through a column of Chelex-100 resin. The ability of both steroid-bound and unliganded receptors to be transformed to the DNA-binding state when either whole cytosol or Chelex-treated cytosol is incubated at $15^{\circ} \mathrm{C}$ is shown in Fig. 2. In whole cytosol, unbound receptor is not transformed at all at $15^{\circ} \mathrm{C}$, and steroid-bound 




Fig. 2. Chelex-treatment of cytosol promotes ligandindependent receptor transformation. Chelex-treated or whole cytosol containing steroid-free or steroid-bound receptors was incubated at $15^{\circ} \mathrm{C}$, and at various times, $100 \mu 1$ aliquots were removed and incubated with DNAcellulose at $0^{\circ} \mathrm{C}$. DNA-bound receptor was quantitated by western immunoblotting with ${ }^{125}$ I-conjugated antibody as described under "Experimental". (O), unliganded receptor in whole cytosol, $\mathrm{R} ;(\mathbf{O})$, steroid-bound receptor in whole cytosol, RS; (A), unliganded receptor in Chelex-treated cytosol, $\mathbf{C R} ;(\triangle)$, steroid-bound receptor in Chelex-treated cytosol, CRS.

receptors undergo slow transformation. In contrast, receptors in Chelex-treated cytosol are rapidly transformed to the DNA-binding state, regardless of whether they are bound with steroid or not. At $0^{\circ} \mathrm{C}$, there is no transformation of steroid-free or steroidbound receptors in Chelex-treated cytosol (data not shown).

These data suggest that by removing a metal (or metals) from the cytosol we have destabilized the glucocorticoid receptor complex, permitting transformation of the receptor to the DNA-binding state in a temperature-dependent, but steroid-independent manner. We would speculate that this endogenous metal (or metals) is involved in conferring the property of steroid-dependency to the receptor transformation event. It is possible that the binding of steroid to the receptor somehow leads to a decreased affinity for the metal. This, in turn would facilitate temperature-mediated dissociation of the $9 \mathrm{~S}$ receptor complex and lead to derepression of DNA binding activity.

Acknowledgements - The authors thank Dr R. W. Harrison for generously supplying the BUGR2 antibody. This investigation was supported by Grant DK31573 from the National Institutes of Health.

\section{REFERENCES}

1. Sanchez E. R., Toft D. O., Schlesinger M. and Pratt W. B.: Evidence that the $90-\mathrm{kDa}$ phosphoprotein associated with the untransformed L-cell glucocorticoid receptor is a murine heat shock protein. J. biol. Chem. 260 (1985) 12398-12401.

2. Sanchez E. R., Meshinchi S., Tienrungroj W., Schlesinger M. J., Toft D. O. and Pratt W. B.: Relationship of the $90-\mathrm{kDa}$ murine heat shock protein to the untransformed and transformed states of the $\mathrm{L}$ cell glucocorticoid receptor. J. biol. Chem. 262 (1987) 6986-6991.

3. Denis M., Poellinger L., Wikstrom A. and Gustafsson $\mathrm{J}$.: A requirement of hormone for thermal conversion of the glucocorticoid receptor to a DNA-binding state. Nature 333 (1988) 686-688.

4. Meshinchi S., Grippo J. F., Sanchez E. R., Bresnick E. H. and Pratt W. B.: Evidence that the endogenous, heat-stable glucocorticoid receptor stabilizing factor is a metal component of the untransformed receptor complex. J. biol. Chem. 263 (1988) 16809-16817.

5. Gametchu B. and Harrison E. W.: Characterization of a monoclonal antibody to the rat liver glucocorticoid receptor. Endocrinology 114 (1984) 274279.

6. Leach K. L., Grippo J. F., Housley P. R., Dahmer M. K., Salive M. E. and Pratt W. B.: Characteristics of an cndogenous glucocorticoid receptor stabilizing factor. J. biol. Chem. 257 (1982) 381-388. 